\title{
The Changes in Intraocular Pressure and Central Corneal Thickness in the First 24 Hours of Life in Full-term Newborns
}

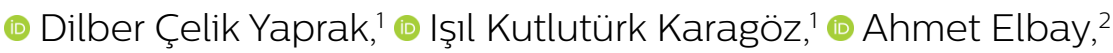 \\ (1) Bilge Tanyeri Bayraktar, ${ }^{3}$ (1) Gökhan Kılıç4
}

\begin{abstract}
'Department of Ophthalmology, Ümraniye Training and Research Hospital, Istanbul, Turkey ${ }^{2}$ Department of Ophthalmology, Bezmialem University Faculty of Medicine, İstanbul, Turkey ${ }^{3}$ Department of Pediatrics, Bezmialem University Faculty of Medicine, Istanbul, Turkey

${ }^{4}$ Department of Obstetrics and Gynecology, Bezmialem University Faculty of Medicine, İstanbul, Turkey
\end{abstract}

Submitted: 19.07.2018 Accepted: 24.09 .2018

Correspondence: Dilber Çelik Yaprak, Ümraniye Eğitim ve Araştırma Hastanesi, Göz Hastalıkları Klinği, İstanbul, Turkey E-mail:dr.dilber_celik@hotmail.com

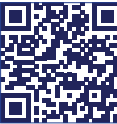

Keywords: Central corneal thickness; full-term newborns; Intraocular pressure.

\begin{abstract}
Objective: This study aims to evaluate the changes in intraocular pressure (IOP) and central corneal thickness (CCT) in the first 24 hours of life in full-term newborns and their reasons.

Methods: The IOP and CCT measurements were determined by using Tono-Pen XL tonometer and portable pachymeter. In this prospective study, we evaluate IOP and CCT of the 32 right eyes of 32 newborn infants born by vaginal delivery. The IOP and CCT measurements taken at the fifth minute just after the delivery and $24^{\text {th }}$ hour of the first day of the postpartum period were recorded. Infants' weights, heights, gender, APGAR (appearance, pulse, grimace, and respiration) scores, and gestational ages were obtained.
\end{abstract}

Results: The mean IOP and CCT of right eyes decreased significantly from $18.67 \pm 3.28$ $\mathrm{mmHg}$ and $684.72 \pm 58.79 \mu \mathrm{m}$ at the $5^{\text {th }}$ minute after delivery to $16.10 \pm 2.87 \mathrm{mmHg}$ and $6 \mathrm{II} .28 \pm 49.4 \mathrm{I} \mu \mathrm{m}$ at the $24^{\text {th }}$ hour of the postpartum period $(\mathrm{p}<0.000 \mathrm{I})$. In terms of IOP and CCT, there was no statistically significant difference at any measurement point between the right and left eyes.

Conclusion: We found that the mean IOP and CCT decreased significantly between the values at the $5^{\text {th }}$ minute after delivery and the $24^{\text {th }}$ hour of the postpartum period. More research is required to investigate the changes and the causes in IOP and CCT of newborns.

\section{INTRODUCTION}

In previous studies, intraocular pressure (IOP) and central corneal thickness (CCT) have been evaluated in newborns. ${ }^{[1-5]}$ In addition, CCT and IOP have been evaluated in the first hours of the peripartum period..$^{[6]}$ The birth stress culminates high plasma adrenaline and noradrenaline levels in infants during the peripartum period. ${ }^{[7-10]}$ Emotional stress increases IOP in humans and animals. ${ }^{[1-12]} \mathrm{By}$ this way, the high IOP might be the result of the hormonal rising and the emotional stress in newborns.

$\mathrm{CCT}$, which is high in newborns, decreases over time. ${ }^{[1-2]}$ However, while in the intrauterine period, the corneal hydration is poor due to the closed fetal eyes, CCT continues to increase in the fetus until the birth time. The corneal endothelial pump activity starts to increase in newborns immediately after birth. Hence, it is better to control postnatal corneal hydration and CCT decreases in the first days of life. ${ }^{[6,13]}$

The corneas of newborns are edematous, and both CCT and peripheral corneal thickness are high. Tono-Pen $\mathrm{XL}$ and iCare have recently been claimed to be better in measuring IOP in edematous corneas. Therefore, they are suitable devices to evaluate IOP in newborns. ${ }^{[14]}$

We prospectively studied the changes in IOP and CCT in the first 24 hours of life in newborns in this study. We also aimed to understand whether there was a relation between the percentage changes in IOP and CCT.

\section{MATERIAL AND METHODS}

This study was conducted in accordance with ethical standards stated in the 1964 Declaration of Helsinki. The study was approved by the ethics board committee of the 
hospital. All families were informed about the procedures, and informed consents were obtained.

In this prospective study, we evaluated IOP and CCT of all eyes of 32 newborns born by normal vaginal delivery. The data included the IOP and CCT measurements taken at fifth minute just after the delivery and $24^{\text {th }}$ hour of the first day of the postpartum period. Infants' weights, heights, gender, APGAR (appearance, pulse, grimace, respiration) scores, and gestational ages were also obtained. Infants weighing higher than $2500 \mathrm{~g}$, APGAR score higher than 8, and gestational age higher than 38 weeks were included in the study. Newborns with ocular abnormalities such as anterior segment abnormalities, lens opacities, retinopathy and optic disc abnormalities, and systemic syndromes were excluded from the study. Infants with forceps delivery and traumas to ocular structures were also excluded.

The ophthalmic examination and measurements were performed by the same ophthalmologist. The measurements were done with the infants in supine position, and lid speculum was not used. As a topical anesthetic, drop of $0.5 \%$ proparacaine hydrochloride was applied. The IOP measurements were done by using Tono-Pen XL (Reichert, Inc., Depew, NY). The CCT evaluations were performed by ultrasonic pachymetry (Compact Touch 3-in-I Ultrasound system; Cedex, France). The readings were taken three times, and the average of the measurements was noted.

A statistical analysis of the study was carried out using the SPSS 20.0 package for Macintosh. Definitive statistics of categorical variables were explained by frequency and percentages, while the definitive statistics of continuous variables were explained by mean, standard deviation, median, minimum, and maximum. The normal distribution of continuous variables was defined with the Shapiro-Wilk test. To compare variables that display normal distribution and non-normal distribution, the independent sample $t$ test and the Mann-Whitney $U$ test, respectively, were employed. Correlations between the continuous variables were examined with Pearson correlation analysis. For every analysis in the study, p levels below 0.05 were regarded statistically significant.

\section{RESULTS}

A total of 32 vaginally delivered newborns ( 14 males [44\%] and 18 females [56\%]) were included in this study. The mean gestational age of infants at birth was $39.4 \pm 0.98$ weeks, and it varied between 38 and $4 \mathrm{I}$ weeks. The mean birth weight of infants was $3504 \pm 349 \mathrm{~g}$ (range: $2890-4450$ g). Table I summarizes the demographic and clinical characteristics of the subjects.

None of the eyes had evidence of congenital glaucoma. The mean IOP value of the right eye at the $5^{\text {th }}$ minute significantly decreased from $18.67 \pm 3.28 \mathrm{mmHg}$ (range 13.50$26.50 \mathrm{mmHg}$ ) to $16.10 \pm 2.87 \mathrm{mmHg}$ (range $11.30-22.70$ $\mathrm{mmHg})$ at 24 hours postpartum $(\mathrm{p}<0.000 \mathrm{l})$. The mean central corneal thickness of right eyes was measured as
Table I. Demographic characteristics of the participants

\section{n $\%$ Mean \pm SD Median}

(Range)

\begin{tabular}{lll}
\hline Gender & & \\
Male & 14 & 44 \\
Female & 18 & 56
\end{tabular}

Mother's age (years)

$28.47 \pm 4.98$

Mother's number of birth $\quad 1.91 \pm 0.89$

APGAR score

Gestation week

$9(8-10)$

Infant weight $(g)$

$39.4 \pm 0.98$

Infant height $(\mathrm{cm})$

$3504 \pm 349$

$50.53 \pm 1.32$

SD: Standard deviation

Table 2. Infant measurements at $5^{\text {th }}$ minute and $24^{\text {th }}$ hour

\begin{tabular}{|c|c|c|c|}
\hline & \multirow{2}{*}{$\begin{array}{l}5^{\text {th }} \text { minute } \\
\text { Mean } \pm S D\end{array}$} & \multirow{2}{*}{$\begin{array}{l}24^{\text {th }} \text { hour } \\
\text { Mean } \pm \text { SD }\end{array}$} & \multirow[t]{2}{*}{$\mathbf{p}^{*}$} \\
\hline & & & \\
\hline IOP right $(\mathrm{mmHg})$ & $18.67 \pm 3.28$ & $16.10 \pm 2.87$ & $<0.0001$ \\
\hline IOP left $(\mathrm{mmHg})$ & $18.59 \pm 3.21$ & $16.24 \pm 2.59$ & $<0.0001$ \\
\hline$P^{* *}$ & 0.924 & 0.831 & \\
\hline $\mathrm{CCT}$ right $(\mu \mathrm{m})$ & $684.72 \pm 58.79$ & $611.28 \pm 49.41$ & $<0.0001$ \\
\hline CCT left $(\mu \mathrm{m})$ & $685.97 \pm 62.26$ & $608.25 \pm 52.57$ & $<0.0001$ \\
\hline$P^{* *}$ & 0.934 & 0.813 & \\
\hline
\end{tabular}

*Paired samples t-test; **Independent samples t-test. IOP: Intraocular pressure; CCT: Central corneal thickness; SD: Standard deviation.

$684.72 \pm 58.79 \mu \mathrm{m}$ (range 584-813 $\mu \mathrm{m}$ ) and $61 \mathrm{I} .28 \pm 49.4 \mathrm{I}$ $\mu \mathrm{m}$ (range $518-719 \mu \mathrm{m})$ at the $5^{\text {th }}$ minute and $24^{\text {th }}$ hour of the postpartum period, respectively $(p<0.000 \mathrm{I})$. No statistically significant difference was found between the IOP and CCT measurements between right and left eyes (Table 2).

No significant correlation was observed between the IOP at the 5th minute after delivery and infant weight $(p=0.465, r=0.134)$, infant height $(p=0.469, r=-0.134)$, gestation week $(p=0.656, r=-0.082)$, APGAR score $(p=0.33$ I, $r=0.177)$, mother's age $(p=0.746, r=0.746)$, mother's number of birth $(p=0.489, r=-0.127)$, or CCT $(p=0.544$, $r=0.11 \mathrm{I}$ ). In addition, no significant correlation was found between the changes of IOP and CCT $(p=0.273, r=0.200)$.

\section{DISCUSSION}

In previous studies, IOP and CCT have been measured in newborns in different periods after delivery. In our study, we measured the changes IOP and CCT values after birth and after 24 hours of full-term in vaginally delivered newborns.

Glucocorticoids and catecholamines have high blood values in newborns. In previous studies, it was suggested that this is owing to increased physical and emotional stresses 
during labor. ${ }^{[7,8]}$ Rising glucocorticoid levels because of psychological stress lead to an increase in IOP in adults and animals. ${ }^{[I]}$ The cause of increase in IOP may be the stresses during birth period.

In our study, the $5^{\text {th }}$ minute mean IOP decreased significantly after 24 hours from the delivery, and the mean IOP of the both eyes wasn't significantly different. In a previous study, the effect of delivery types on IOP and CCT and the alterations in values after delivery have been reported by Ozkurt et al. ${ }^{[6]}$ Similar to our results, they reported that IOP decreased at the 12 th hour compared to 5 th minute value. The fall in the IOP values in the newborns may be due to reduction of the effects of delivery stress associated with the plasma catecholamine levels.

On the other hand, CCT has been assessed in earlier studies in newborns. Rushood at al. ${ }^{[I]}$ established that the mean CCT was $647 \pm 6 \mathrm{I} \mu \mathrm{m}$ at $0-6 \mathrm{~h}$ after delivery and $6 \mathrm{II} \pm 72 \mu \mathrm{m}$ at $7-12 \mathrm{~h}$ after delivery. The mean values of this study were lower than those of ours. This can be explained by the fact that our measurement time is earlier.

Ozkurt at al. ${ }^{[6]}$ have noticed a drop in CCT in newborns in the first hours after delivery. In our study, this drop was very significant in the $24^{\text {th }}$ hour compared to the fifth minute after delivery. This reduction may be because of the development of corneal hydration control, evaporation, and corneal remodeling in the postpartum period. ${ }^{[2-5]}$ The corneal pump function in the fetal corneas is weak, so the liquid concentrates in the intracellular space. The activation of corneal pump system, which allows the liquid to exit into the extracellular space, increases in newborns' corneas. ${ }^{[15]}$ Also, protracted closed fetal eyes are possible reason for the thicker corneas in the first hours after delivery. Protracted closed fetal eyes and condensation of liquid in the intracellular space may result in the edematous cornea and thicker cornea. In previous studies, one of the causes of the increased corneal pump system function was the catecholamine. ${ }^{[16,17]}$ The corneal endothelial pump system may be activated by the high plasma catecholamine levels in newborns. As a result, CCT decreases over time.

Uva et al. ${ }^{[3]}$ reported that IOP increased with CCT, and CCT decreased with increase in birth weight. However, in our study, IOP did not relate with infant weight, infant height, gestation week, APGAR score, mother's age, or mother's number of birth.

Especially, we did not use eyelid speculum to evaluate IOP in our study. Because Epley et al. ${ }^{[18]}$ reported that use of eyelid speculum to measure IOP increased it on average by $4 \mathrm{mmHg}$ in children.

Although the Goldmann Applanation Tonometer is the best device to evaluate IOP, lester et al. ${ }^{[19]}$ reported that no significant difference was found among the measurements taken with the Goldmann Tonometer and Tono-Pen. Also, Tono-Pen $\mathrm{XL}$ and iCare have currently been claimed to be better in measuring IOP in edematous corneas..$^{[14]}$ In addition, topical anesthesia is sufficient for IOP measurement by these instruments. Hence, Tono-pen and iCare are par- ticularly useful in children both in first visit and in followup visits. Consequently, Tono-Pen seems to be a suitable device to evaluate IOP in newborns because of topical anesthesia and its easy handing at lie-down position.

In conclusion, we found that the mean IOP and CCT decreased significantly between the $5^{\text {th }}$ minute after delivery and the $24^{\text {th }}$ hour of the life. Birth stress and hormonal factors are very effective in the alterations in IOP and CCT in newborns in the first days. Our study reports that there was no correlation between IOP and CCT, infant weight, infant height, gestation week, APGAR score, mother's age, and mother's number of birth. The relatively small number of cases is the shortcoming of this study, and it will be useful to examine this relationship again with more cases. Nevertheless, we think that there may be other ocular and systemic factors that affect the change in the IOP in newborns. Further studies are required to investigate the changes and their causes in IOP and CCT in newborns.

Ethics Committee Approval

Approved by the local ethics committee.

Informed Consent

Prospective study.

Peer-review

Internally peer-reviewed.

Authorship Contributions

Concept: A.E, G.K; Design: D.Ç.Y, I.K.K; Data collection \&/or processing: A.E, B.T.B; Analysis and/or interpretation: D.Ç.Y, I.K.K; Literature search: A.E, I.K.K; Writing: D.Ç.Y, I.K.K; Critical review: A.E, D.Ç.Y.

\section{Conflict of Interest}

None declared.

\section{REFERENCES}

1. Rushood AA, Zahrani MH, Khamis A, Rushood AA. Central corneal thickness in full-term Saudi newborns. Acta Ophthalmol 2012;90:e355-8.

2. Remón L, Cristóbal JA, Castillo J, Palomar T, Palomar A, Pérez J. Central and peripheral corneal thickness in full-term newborns by ultrasonic pachymetry. Invest Ophthalmol Vis Sci 1992;33:3080-3.

3. Uva MG, Reibaldi M, Longo A, Avitabile T, Gagliano C, Scollo D, et al. Intraocular pressure and central corneal thickness in premature and full-term newborns. J AAPOS 2011;15:367-9.

4. Reddy SC, Alias R. Tono-pen measurement of intraocular pressure under topical anaesthesia in full term normal newborns. Int J Ophthalmol 2014;7:92-4.

5. Kirwan C, O'Keefe M, Fitzsimon S. Central corneal thickness and corneal diameter in premature infants. Acta Ophthalmol Scand 2005;83:751-3.

6. Ozkurt ZG, Balsak S, Balsak B, Guclu H, Sahın M, Yuksel H, et al. The effects of delivery type and gender on intraocular pressure and central corneal thickness in newborns. Arq Bras Oftalmol 2016;79:92-5.

7. Schuller C, Känel N, Müller O, Kind AB, Tinner EM, Hösli I, et al. Stress and pain response of neonates after spontaneous birth and vacuum-assisted and cesarean delivery. Am J Obstet Gynecol 2012;207:416.e1-6. 
8. Faxelius G, Lagercrantz H, Yao A. Sympathoadrenal activity and peripheral blood flow after birth: comparison in infants delivered vaginally and by cesarean section. J Pediatr 1984;105:144-8.

9. Otamiri G, Berg G, Ledin T, Leijon I, Lagercrantz H. Delayed neurological adaptation in infants delivered by elective cesarean section and the relation to catecholamine levels. Early Hum Dev 1991;26:51-60.

10. Dawson JA, Kamlin CO, Wong C, te Pas AB, Vento M, Cole TJ, et al. Changes in heart rate in the first minutes after birth. Arch Dis Child Fetal Neonatal Ed 2010;95:F177-81.

11. Brody S, Erb C, Veit R, Rau H. Intraocular pressure changes: the influence of psychological stress and the Valsalva maneuver. Biol Psychol 1999;51:43-57.

12. Miyazaki Y, Matsuo T, Kurabayashi Y. Immobilization stress induces elevation of intraocular pressure in rabbits. Ophthalmic Res 2000;32:270-7.

13. al-Umran KU, Pandolfi MF. Corneal diameter in premature infants. Br J Ophthalmol 1992;76:292-3.
14. Neuburger M, Maier P, Böhringer D, Reinhard T, F Jordan J. The impact of corneal edema on intraocular pressure measurements using goldmann applanation tonometry, Tono-Pen XL, iCare, and ORA: an in vitro model. J Glaucoma 2013;22:584-90.

15. Aggarwal R, Deorari AK, Paul VK. Fluid and electrolyte management in term and preterm neonates. Indian J Pediatr 2001;68:1139-42.

16. Hatou $\mathrm{S}$. Hormonal regulation of $\mathrm{Na}+/ \mathrm{K}+$-dependent ATPase activity and pump function in corneal endothelial cells. Cornea 2011;30:S60-6.

17. Hatou S, Yamada M, Mochizuki H, Shiraishi A, Joko T, Nishida T. The effects of dexamethasone on the Na,K-ATPase activity and pump function of corneal endothelial cells. Curr Eye Res 2009;34:347-54.

18. Epley KD, Tychsen L, Lueder GT. The effect of an eyelid speculum on intraocular pressure measurement in children. Am J Ophthalmol 2002;134:926-7.

19. Iester M, Mermoud A, Achache F, Roy S. New Tonopen XL: comparison with the Goldmann tonometer. Eye (Lond) 2001;15:52-8.

\section{Matür Yenidoğanlarda Doğumdan Sonraki Illk 24 Saatte Göz İçi Basıncı ve Santral Korneal Kalınlık Değerlerinin Değişimi}

Amaç: Matür yenidoğanlarda doğumdan sonraki ilk 24 saatte göz içi basıncı (GiB) ve santral korneal kalınlıktaki (SKK) değişimi, bu değişimin sebeplerini ve GiB ile SKK arasındaki ilişkiyi araştırmak.

Gereç ve Yöntem: Göz içi basıncı Tono-Pen XL ile,SKK ise taşınabilir ultrasonografik pakimetri ile ölçüldü. İleriye dönük olarak yaptığımız bu çalışmada vajinal doğum sonrası 32 yenidoğanın 32 sağ ve sol gözünün GiB ve SKK'sını ölçtük ve verilerini kaydettik. Göz içi basıncı ve SKK değerleri doğum sonrası beşinci dakikada ve 24. saatte alındı. Yeni doğanların kiloları, boyları, cinsiyetleri, APGAR (Appaerance, Pulse, Grimace, Respiration) skorları ve doğum haftaları kaydedildi. Ağılı̆̆ı $\leq 2500$, APGAR skoru $\leq 8$, doğum haftası $\leq 38$ olgular çalışmaya dahil edildi. Korneal ve iris gibi oküler anomalileri, konjenital katarakt, retinopati ve glokomatöz optik disk değişiklikleri (C/D>0.4) olanlar çalışma dışı bırakıldı.

Bulgular: Sağ gözlerin ortalama GiB değerleri doğum sonrası beşinci dakikada $18.67 \pm 3.28 \mathrm{mmHg}$ 'dan 24. saatte $16.10 \pm 2.87 \mathrm{mmHg}$ ', SKK değerleri beşinci dakikada $684.72 \pm 58.79 \mu$ m'den 24. saatte $6 \mathrm{II} .28 \pm 49.4 \mathrm{I} \mu$ m'e anlamlı olarak düşüş gösterdi $(p<0.000 \mathrm{I})$. Sağ sol göz arasında ortalama GiB ve SKK değerlerinde anlamlı fark bulunamadı. Göz içi basıncı ve SKK değerleri, yeni doğanın kilosu, boyu, doğum haftası, APGAR skoru, annenin yaşı arasında korelasyon bulunamadı.

Sonuç: Doğum sonrası beşinci dakikada ve 24. saatte ölçülen ortalama GiB ve SKK değerleri arasında anlamlı bir düşüş kaydettik. Yenidoğanlarda GiB ve SKK değerlerinde değişim ve bunun sebeplerini araştıran daha çok çalışmaya ihtiyaç vardır.

Anahtar Sözcükler: Erken evre akciğer kanseri; küçük hücre dışı akciğer kanseri; stereotactic radyoterapi. 